\title{
ОСОБЛИВОСТІ НАДАННЯ ПУБЛІЧНИХ ПОСЛУГ ЩОДО РЕЕСТРАЦІЇ МІСЦЯ ПРОЖИВАННЯ ОСОБИ
}

\author{
ІВАНОВ Сергій \\ Миколайович \\ - суддя \\ третього \\ апеляційного \\ адміністративного суду \\ УДК $351.74: 342.922$ \\ https://orcid.org/0000-0001-5090-6247 \\ DOI 10.32782/NP.2021.2.12
}

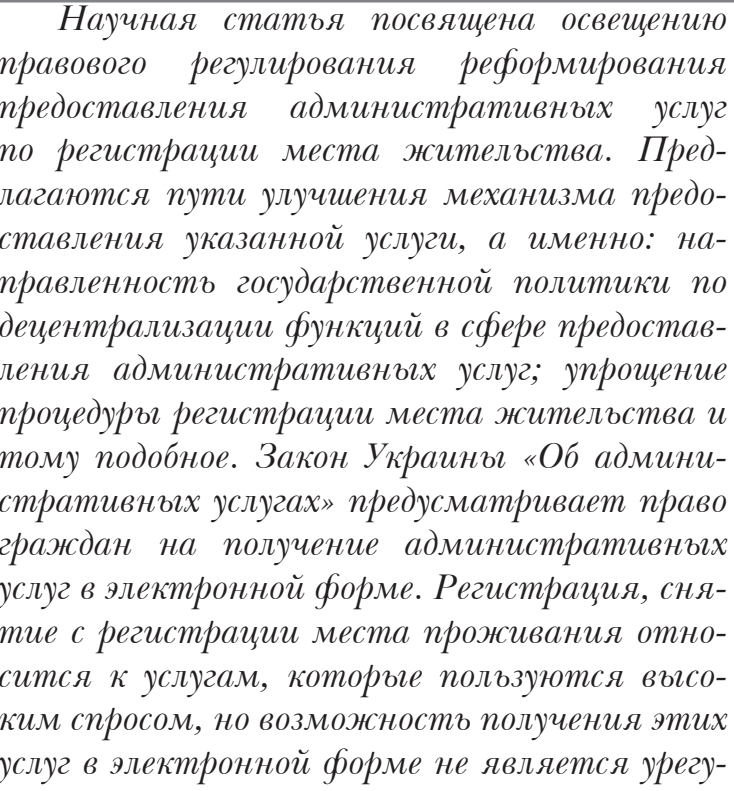
лированной на уровне законодательства.

Вместе с тем, анализ функииональных возможностей национальных электроннъх информачионньхх ресурсов свидетельствует о том, ито услуга по регистраиии, снятия с регистрации места проживания в электронной борме может быть доступна гражданам Украинъ при условии надлежащей наполненности и взаимодействия национальных электроннъих инбормационнъих ресурсов.

Проблемь учета населения обостряются из-за того, ито реестры территориальных общин являются автономными, имеют различное программное обеспечение и не взаимодействуют между собой. Кроме того, только часть реестров ведется территориальньми обшинами в электронной борме или имеет связь через систему электронного взаимодействия государственных электронных инбормационных ресурсов с ведомственной инбормационной системой центрального органа исполнительной власти, реализующего государственную политику в сфьере регистрации физических лич и Едином государственном демограбическом реестре. Поэтому не только регистрачия, а и получение информачии из реестров (например, сведений о месте жительства) превращается для гражданина в длительнылй процесс, в то время как эту информацию можно было бы за сиитаннъие секунды получать с помощью программных средств.

Ключевъе слова: административная услуга, электроннъле услуги, услуга, публичная услуга, регистрация места жительства.

\section{Постановка проблеми}

Беззаперечно, важливого значення мають зусилля держави, що вживаються для гарантування громадянства, імміграції та реєстрації фізичних осіб, яка знаходиться в режимі довгострокової антитерористичної операції i, одночасно, на початку євроінтеграційних процесів. Складність, масштабність економічних, політичних проблем досягли пікового значення з часів здобуття незалежності Україною. Іноді проблеми, що мають місце в системі державних гарантій щодо громадянства, імміграції та реєстрації фізичних осіб поєднані 3 помилками в організації надання адміністративних послуг. Ефективність зусиль з налагодження систе- 


\section{Адміністративне право}

ми громадянства, імміграції та реєстрації фізичних осіб безпосередньо залежить і від ступеня наукової обгрунтованості ухвалених рішень, що вимагає багатостороннього наукового аналізу, а також уточнення, систематизації категорійного апарату.

\section{Огляд останніх досліджень та публікацій}

Варто зазначити, що адміністративноправові аспекти вивчення громадянства, міграції (еміграції; імміграції) та реєстрації фізичних осіб в Україні певною мірою досліджуються в юридичній літературі. Серед українських авторів, які займались цією проблемою, можна назвати таких науковців, як О.О. Бандурка, О.О. Воронятніков, I.B. Михайлишин, С.О. Мосьондз, В.І. Олефір, Я.А. Поєдинок, С.С. Саїв, А.А. Савранчук, О.П. Сікорський, Е.В. Стрільченко, A.I. Супруновський та інші.

Проблеми діяльності органів публічної влади 3 надання адміністративних послуг досліджували такі вчені-адміністративісти, як В.Б. Авер'янов, К.К. Афанасьєв, В.М. Бевзенко, Ю.П. Битяк, М.Ю. Віхляєв, В.М. Гаращук, І.П. Голосніченко, С.В. Ківалов, Н.В. Коваленко, І.Б. Коліушко, Т.О. Коломоєць, В.К. Колпаков, А.Т. Комзюк, Е.О. Аегеза, П.С. Аютіков, Р.С. Мельник, Г.М. Писаренко, В.П. Тимощук та інші. Однак питання публічних послуг щодо реєстрації місця проживання особи у наукових дослідженнях окремо не вивчалися. Саме вказані обставини зумовили обрання цієї теми.

Метою статті є розкриття особливостей надання публічних послуг щодо реєстрації місця проживання особи.

\section{Виклад основного матеріалу}

4 квітня 2016 року набрали чинності норми закону №888-VIII «Про внесення змін до деяких законодавчих актів України щодо розширення повноважень органів місцевого самоврядування та оптимізації надання адміністративних послуг», що торкаються сфери реєстрації місця проживання [1].

Як правильно зазначає експерт центру політико-правових реформ Є. Школьний, насправді, зміни - не суттєві косметичні. Aле потрібні справжні зміни в інтересах громадян. I їх може зробити новий уряд [2].

Тепер замість Державної міграційної служби України для реєстрації місця проживання треба звертатися до виконавчого органу місцевої ради або ж до сільського голови, якщо не утворений виконавчий орган сільської ради.

Навіть якщо нове місце проживання особи знаходиться в іншій адміністративнотериторіальній одиниці, то реєстраційний орган все одно самостійно надсилатиме повідомлення про зняття особи з реєстрації за попереднім місцем проживання особи [2].

Щодо розміру плати за реєстрацію місця проживання, то спостерігається підвищення. Якщо раніше вартість реєстрації становила 0,05 неоподаткованого мінімуму доходів громадян - 85 копійок, то зараз реєстрація коштуватиме 0,0085 розміру мінімальної заробітної плати - біля 12 гривень.

Наступний елемент змін у цьому питанні стосується пом'якшення адміністративної відповідальності за проживання без реєстрації місця проживання. Якщо раніше передбачались як попередження, так і штраф - то тепер залишили лише попередження. Воно застосовуватиметься до осіб, які цілеспрямовано прибули реєструвати нове місце проживання, проте після зняття з реєстрації попереднього місця проживання вже спливло 30 календарних днів.

Отже, певні зміни дійсно відбулись щодо регулювання реформування надання адміністративних послуг з реєстрації місця проживання особи.

Однак сама дозвільна модель реєстрації місця проживання, тобто система, що успадкована Україною з часів існування СРСР, за якої особа жорстко «прив’язана» до прописаної адреси у паспорті, - залишається.

Закон стосується насамперед процесу 3 децентралізації влади. У громадян більше немає потреби звертатися до Державної міграційної служби, і вони можуть отримати цю послугу максимально близько до свого місця проживання та набагато швидше. Адже тепер послугу можна отримати навіть у селі, де є виконавчий орган чи сільський голова. 
Крім того, для отримання послуги тепер доведеться витрачати замість 3 днів, як це було фактично, адже документи 3 центрів надання адміністративних послуг передавалися до Державної міграційної служби і назад у зворотному порядку, до 30 хвилин.

Однак щодо самого змісту «реєстрації місця проживання» та процедури - зміни наразі не принципові.

Громадяни й надалі мусять збирати документи та підтверджувати право проживання у житлі для цієї реєстрації, оскільки перелік документів, необхідний для цієї процедури, не зазнав суттєвих змін [2].

А без цього, у свою чергу, неможливо отримувати більшість адміністративних і соціальних послуг.

Щодо процедури реєстрації місця проживання насправді, то необхідно зазначити що особливих змін не відбулося. Відбулась лише перестановка зміни суб'єкта надання адміністративних послуг, у тому числі з реєстрації місця проживання, та скасування талонів на реєстрацію. Однак це не може вважатись зміною самої процедури чи, навіть, системи, як про це декларували заголовки українських 3МI.

Тож, по суті, система все ще потребує суттєвого реформування та адаптування під сучасні потреби населення.

Сучасний уряд має пам'ятати, що за кожною людиною, яка мешкає на території України, Конституцією України [3] закріплено цілий ряд прав, які по суті є непорушними. Але практично до сьогоднішнього дня більше ніж третина населення, намагаючись зреалізувати свої права, може отримати переважну більшість необхідних від держави послуг винятково за місцем реєстрації у паспорті, а не за фактичним місцем проживання.

До прикладу, якщо людина, звернувшись за послугою в державну установу, не має підтвердження «прописки» того мікрорайону, за яким відбулось звернення, шанс бути обслуженим без так званого «добровільного внеску» або «подяки» зводиться до нуля в багатьох випадках.

«Подвійні стандарти» обслуговування громадян можна зустріти майже в кожній державній установі країни, звернувшись не за місцем реєстрації щодо:
- поліклінічного/медичного обслуговування;

- надання соціальної допомоги при народженні дитини;

- реєстрації місця проживання дитини;

- отримання ідентифікаційного коду платника податку, обслуговування фізичних осіб-підприємців у податкових органах;

- призначення пенсії за віком, пенсії по інвалідності, пенсії у зв' язку з втратою годувальника, пенсії за вислугу років.

Незареєстровані мешканці не можуть взяти участь у місцевих виборах. А для участі в президентських, парламентських та місцевих виборах їм потрібно їздити в громади, де реально вони не живуть, а є лише зареєстрованими.

Тарифікація комунальних послуг у будинках без лічильників прив'язана до кількості зареєстрованих мешканців, частина 3 яких, по факту, може там і не проживати.

Упродовж усього терміну незалежності система реєстрації місця проживання в Україні лише ускладнювала життя людям. Настав час визнати, що вона вже давно не відповідає сучасним потребам динамічного життя в Україні.

На наш погляд, потребує удосконалення модель реєстрації місця проживання шляхом внесення змін до підзаконних нормативно-правових актів в інтересах громадян, а саме: реєстрація адреси проживання особи здійснюється на підставі повідомлення (заяви) особи, без документального підтвердження підстав для проживання у житлі [1].

Така система діє в багатьох країнах цивілізованого світу: СІІ, Канада, Великобританія, Ірландія, Швеція, Фінляндія.

Це може викликати побоювання у власників житла, але їх права є захищеними, оскільки реєстрація місця проживання не прив' язана до права власності на житло.

Орендар житла може зареєструвати проживання у житлі власника без його попереднього оголошення, а власник житла уповноважений виселити орендаря відповідно до умов договору та норм закону.

Швидкість та прозорість процесу дозволятиме громадянам миттєво розпочати отримання всіх адміністративних та соці- 


\section{Адміністративне право}

альних послуг саме за реальним місцем проживання.

Ще одна важлива перевага повідомної системи, над якою варто замислитись чинному Уряду, - це можливість залагодити конфлікт інтересів між громадянами, які змінили місце проживання, та приймаючими громадами.

Якщо повноцінно вступить у дію повідомна система реєстрації місця проживання - наново зареєстровані мешканці громад сплачуватимуть податки в місцеві бюджети, а установи, які займаються розрахунком інфраструктурного розвитку, матимуть можливість бачити реальну кількість жителів та залучити співставне бюджетування на підтримку та розвиток [4, с. 129].

Повідомна система відповідає сучасній динаміці міграції та здатна забезпечити максимальний комфорт громадянам під час отримання соціальних, комунальних та адміністративних послуг, сплаті податків.

3 іншого боку, зі зміною на повідомну систему, громадяни більше не муситимуть долати велику відстань для того, щоб проголосувати на виборах за місцем «прописки». За повідомної системи громадянин отримує можливість голосувати в тому населеному пункті, де він мешкає по факту, сплачує податки та є повноправним членом громади.

За останні два роки, у світлі дуже високої внутрішньої міграції громадян унаслідок збройних конфліктів та тимчасової окупації українських територій, зміна системи набула актуальності, як ніколи раніше. I саме активність вітчизняних 3МI на тему зміни системи реєстрації є чітким сигналом уряду до дії [4, с. 130].

Необхідно почати проводити громадські обговорення щодо цієї тематики, затвердити на їх основі Концепцію реформування системи реєстрації місця проживання в Україні, розробити відповідні законопроєкти та чіткий план реалізації змін у системі.

\section{Висновки}

Отже, публічна послуга 3 реєстрації місця проживання є однією 3 найпопулярніших серед усього переліку послуг. Натомість, власне процедура реєстрації є архаїчною і ускладненою - для реєстрації місця проживання необхідно зібрати 3-5 документів та погоджень і прибути з ними до органу реєстрації чи центру надання адміністративних послуг.

Наявний стан справ 3 реєстрацією місця проживання також порушує покладений в основу державної політики у сфері надання адміністративних послуг принцип раціональної мінімізації кількості документів та процедурних дій, що вимагаються для отримання адміністративних послуг (стаття 4 Закону України «Про адміністративні послуги»).

Оскільки підставою реєстрації є не фактичне проживання у житлі, а лише наявність права на проживання у ньому, громадяни реєструються не там, де вони фактично проживають, а там, де можуть документально підтвердити право на проживання.

Зв’язок реєстрації місця проживання 3 правом проживання у житлі також створює умови для маніпулювання 3 майновими та житловими правами на житло.

Таким чином, існує нагальна потреба реформування чинного механізму обліку населення в Україні і запровадження інституту декларування місця проживання, що пропонується здійснити шляхом прийняття Закону України «Про реалізацію електронних послуг з реєстрації та декларування місця проживання в Україні».

\section{Лiтература}

1. Про внесення змін до деяких законодавчих актів України щодо розширення повноважень органів місцевого самоврядування та оптимізації надання адміністративних послуг : закон України від 10.12.2015 № 888VIII // Відомості Верховної Ради (ВВР), 2016 , № 3, ст.30

2. Школьний Евген. Реєстрація місця проживання по-новому: косметичні зміни [Електронний ресурс]. - Режим доступу : http://pravo.org.ua/ua/news/20871505reestratsiya-mistsya-progeivannya-po-novomukosmetichni-zmini

3. Конституція України / Верховна Рада України // Відомості Верховної Ради України. - 1996. - № 30. - С. 141.

4. Власенко О. Г. Реформування надання адміністративних послуг щодо реєстрації 


\section{АНОТАЦІЯ}

Наукова стаття присвячена висвітленню правового регулювання ребормування надання адміністративних послуг щодо реєстрацій місия проживання особи. Пропонуються шляхи покрашення механізму надання зазначеной послуги, а саме: спрямованість державної політики щодо дещентралізащиї бункиій у сфбері надання адміністративних послуг; спрощення процедури реєстращй місия проживання особи тощо. Закон України "Про адміністративні послуги» передбачає право громадян на отримання адміністративних послуг в електронній бормі. Реєстрачія, зняття з реєстрачій місия проживання належить до послуг, які мають високий попит, але можливість отримання иих послуг в електронній бормі не $\epsilon$ врегульованою на рівні законодавства.

Разом $з$ тим, аналіз функціональних можливостей національних електронних інформачійних ресурсів свідчить про те, що послуга з реєстраиї, зняття з реєстраиій місия проживання в електронній бормі може бути доступна громадянам України за умови належної наповненості та взаємодї начіональних електронних інформачійних ресурсів.

Проблеми обліку населення загострюються через те, що реєстри територіальних громад $є$ автономними, мають різне програмне забезпечення $i$ не взаємодіють між собою. Крім того, лише частина реєстрів ведеться територіальними громадами в електронній бормі або має зв'язок через систему електронної взаємодї державних електронних інформачійних ресурсів з відомчою інбормаційною системою иентрального органу виконавчой влади, що реалізує державну політику у сбері реєстраиї фбізичних осіб та Единим державним демограбічним реєстром. Тому не лише реєстраиія, а й отримання інформаиій з реестрів (наприклад, відомостей про місче проживання) перетворюеться для громадянина у тривалий процес, у той час як зазначену інбормачію можна було б за лічені секунди отримувати за допомогою програмних засобів.

Ключові слова: адміністративна послуга, електронні послуги, послуга, публічна послуга, реєстрація місия проживання особи.

\section{SUMMARY}

The scientific article is devoted to the coverage of the legal regulation of reforming the provision of administrative services for the registration of a person's place of residence. Ways to improve the mechanism of providing this service are proposed, namely: the direction of state policy on decentralization of functions in the field of administrative services; simplification of the procedure for registration of a person's place of residence, etc. The Law of Ukraine "On Administrative Services" provides for the right of citizens to receive administrative services in electronic form. Registration, deregistration of residence belongs to the services that are in high demand, but the possibility of obtaining these services in electronic form is not regulated by law.

At the same time, the analysis of the functionality of national electronic information resources shows that the service of registration, deregistration of residence in electronic form may be available to citizens of Ukraine provided that the full content and interaction of national electronic information resources.

Problems of population accounting are exacerbated by the fact that the registers of territorial communities are autonomous, have different software and do not interact with each other. In addition, only part of the registers is maintained by local communities in electronic form or has a connection through the system of electronic interaction of state electronic information resources with the departmental information system of the central executive body implementing state policy in the field of registration of individuals and the Unified State Demographic Register. Therefore, not only registration, but also obtaining information from registers (for example, information about the place of residence) becomes a long process for a citizen, while this information could be obtained in seconds with the help of software.

Key words: administrative service, electronic services, service, public service, registration of a person's place of residence.

місця проживання особи. Науковий вісник Херсонського державного університету. Серія «Юридичні науки». 2016. № 3. Т. 1. С. 129-130. 